\title{
Drug induced acute pancreatitis: incidence and severity
}

\author{
P G Lankisch, M Dröge, F Gottesleben
}

\begin{abstract}
To determine the incidence and severity of drug induced acute pancreatitis, data from 45 German centres of gastroenterology were evaluated. Among 1613 patients treated for acute pancreatitis in 1993, drug induced acute pancreatitis was diagnosed in 22 patients (incidence $1.4 \%$ ). Drugs held responsible were azathioprine, mesalazine/sulfasalazine, 2',3'-dideoxyinosine (ddI), oestrogens, frusemide, hydrochlorothiazide, and rifampicin. Pancreatic necrosis not exceeding 33\% of the organ was found on ultrasonography or computed tomography, or both, in three patients $(14 \%)$. Pancreatic pseudocysts did not occur. A decrease of arterial $\mathrm{Po}_{2}$ reflecting respiratory insufficiency, and an increase of serum creatinine, reflecting renal insufficiency as complications of acute pancreatitis were seen in two $(9 \%)$ and four $(18 \%)$ patients, respectively. Artificial ventilation was not needed, and dialysis was necessary in only one $(5 \%)$ case. Two patients $(9 \%)$ died of AIDS and tuberculosis, respectively; pancreatitis did not seem to have contributed materially to their death. In conclusion, drugs rarely cause acute pancreatitis, and drug induced acute pancreatitis usually runs a benign course.
\end{abstract}

(Gut 1995; 37: 565-567)

Keywords: acute pancreatitis, aetiology, drugs.

Ever since the first reports on cortisone ${ }^{1}$ and thiazides ${ }^{2}$ inducing acute pancreatitis, a large number of single case reports were published on - often fatal - drug induced acute pancreatitis. Subsequent review articles criticised the time interval between drug application and the onset of acute pancreatitis, dose, and rechallenge trials. Published reports have identified about 50 drugs that definitely or possibly may be held responsible for inducing acute pancreatitis. ${ }^{3-6}$

Our report deals for the first time with the question of how frequently drug induced acute pancreatitis actually occurs and whether it takes as severe a course as indicated in many case reports.

TABLe I Aetiology of acute pancreatitis in 1613 patients

\begin{tabular}{lc}
\hline Aetiology & No of patients (\%) \\
\hline Alcohol & $729(45 \cdot 2)$ \\
Biliary & $635(39 \cdot 4)$ \\
Other & $92(5 \cdot 7)$ \\
Unknown & $135(8 \cdot 4)$ \\
Drugs & $22(1 \cdot 4)$ \\
\hline
\end{tabular}

\section{Patients and methods}

To determine the incidence of drug induced pancreatitis, we asked 45 German centres of gastroenterology how many patients they had treated in 1993 for acute pancreatitis and how often the aetiology was drug related. To obtain an impression of disease severity, we further asked for the length of the hospital stay, the occurrence of acute respiratory and renal failure, the development of pancreatic pseudocysts and necroses, and resulting death rate.

All data on drug induced pancreatitis were evaluated by us. We included only those patients for whom the centres had already excluded all other aetiologies, except drugs, which have been shown either in published reports or in the specifically reported patient to reinduce acute pancreatitis on rechallenge, or which are among those - according to previous reports - strongly suspected of inducing acute pancreatitis. ${ }^{3-6}$ When fatal outcome was reported, we tried to establish whether this resulted from pancreatitis or the underlying disease.

Each centre was responsible for the exclusion of the main aetiologies of acute pancreatitis, namely alcohol and biliary disease, which was done by means of case history given by the patient or his relatives/friends (alcohol) or ultrasound (biliary disease).

Furthermore, all centres were responsible for the diagnosis of acute pancreatitis, which was usually based on typical signs and symptoms, an increase in enzyme activity, and the signs of the disease upon imaging procedures, such as ultrasound and computed tomography, which were asked for.

\section{Results}

During the 12 month period of 1993,1613 patients with acute pancreatitis had been treated by the 45 participating centres of gastroenterology. Alcoholism was the most prevalent aetiology, followed by biliary tract disease. Smaller groups had other (post-endoscopic retrograde cholangiopancreatography (ERCP), post-traumatic, postoperative, viral genesis) or unknown aetiologies. In 22 patients (12 female, 10 male, mean age 42, range 19-80 years), drug induced acute pancreatitis was diagnosed, the incidence being $1 \cdot 4 \%$ (Table I). Drugs considered responsible were azathioprine $(n=6)$, mesalazine/sulfasalazine $(n=5), 2 ', 3^{\prime}$-dideoxyinosine (ddI) $(n=4)$, oestrogens $(n=3)$, frusemide $(n=2)$, and hydrochlorothiazide and rifampicin $(n=1$ each) (Table II). For ethical reasons, a rechallenge was refused by most participating hospitals and performed with positive results in only three cases (azathioprine, $\mathrm{n}=2$; mesalazine, $n=1$ ) (Table II).

Mean hospital stay was 25.5 days, but varied considerably from patient to patient (range 2-78 days). Less than one third necroses were found on ultrasonography or computed 
TABLE II Severity of the disease in 22 patients with drug induced acute pancreatitis

\begin{tabular}{lcl}
\hline Parameters of severity & No of patients (\%) & Drug \\
\hline Necroses on ultrasound/computed tomography & $19(86)$ & \\
Absent & $3(14)$ & ddI $(2 \times)$ \\
$<33 \%$ & 0 & Azathioprine \\
$33-50 \%$ & 0 & \\
$>50 \%$ & $22(100)$ & \\
Pseudocysts & 0 & \\
Absent & $20(91)$ & \\
Present & $1(5)$ & Rifampicin \\
Acute respiratory failure & $1(5)$ & \\
Po $>70 \mathrm{~mm} \mathrm{Hg}$ & 0 & ddI \\
Po $260-70 \mathrm{~mm} \mathrm{Hg}$ & $17(77)$ & ddI \\
Po & $<60 \mathrm{~mm} \mathrm{Hg}$ \\
Artificial ventilation & $4(18)^{\star}$ & Frusemide \\
Acute renal failure & & Oestrogens \\
Serum creatinine $<1 \cdot 2 \mathrm{mg} / \mathrm{dl}$ & & Hydrochlorothiazide \\
Serum creatinine $>1 \cdot 2 \mathrm{mg} / \mathrm{dl}$ & $1(5)^{\star}$ & Frusemide \\
& $2(9)$ & ddI \\
Dialysis & & Rifampicin \\
\hline Fatal outcome & & \\
\end{tabular}

*One patient with chronic renal failure was excluded.

tomography in three (14\%) patients. None of the patients developed pancreatic pseudocysts. Arterial $\mathrm{PO}_{2}$ was below normal in two $(9 \%)$ patients, but neither required artificial ventilation. Serum creatinine was above normal in five $(23 \%)$, two $(9 \%)$ of them requiring dialysis, of whom one had chronic renal failure. Two $(9 \%)$ patients died, but death was caused by AIDS and tuberculosis, respectively. The first patient had had ddI, the second rifampicin induced acute pancreatitis.

\section{Discussion}

Our data show that drug induced acute pancreatitis occurs rarely in clinical practice and usually takes a benign course.

It may be argued, however, that the retrospective design of our study is a drawback and that in a prospective trial the frequency would have been higher. A prospective trial would mean that all patients receiving drugs definitely or probably associated with acute pancreatitis would have been screened for possible development of acute pancreatitis. Such a study is not easy for several reasons. The number of drugs possibly inducing acute pancreatitis is large ${ }^{36}$; time intervals between first application of any one drug and development of acute pancreatitis differ; and screening procedures for drug induced pancreatitis such as enzyme measurement ${ }^{7}$ and ultrasound examination ${ }^{8}$ may be ineffective.

The low incidence of drug induced acute pancreatitis in our study possibly reflects the normal clinical situation. A higher incidence rate has been found among patients with diseases especially associated with acute

TABLE III Review of published reports on cases and fatal outcome of acute pancreatitis induced by drugs held responsible for the induction of the disease in the reported 22 patients

\begin{tabular}{lll}
\hline Drug & Reported cases & Fatal outcome (\%) \\
\hline Azathioprine & 21 & $5(23 \cdot 8)$ \\
Mesalazine/sulfasalazine & 19 & 0 \\
2',3'-didioxyinosine (ddI) & 35 & $5(14 \cdot 3)$ \\
Oestrogens & 31 & 0 \\
Frusemide & 21 & $3(14 \cdot 9)$ \\
Hydrochlorothiazide & 10 & $5(50 \cdot 0)$ \\
Rifampicin & 15 & 0 \\
\hline
\end{tabular}

pancreatitis, such as inflammatory bowel disease $^{910}$ and AIDS. ${ }^{11-16}$ In inflammatory bowel disease, Haber et al ${ }^{10}$ saw acute pancreatitis in $13(3.3 \%)$ of 400 patients treated with 6-mercaptopurine, and Sturdevant et $a l^{17}$ in six $(5 \cdot 3 \%)$ of 113 patients treated with azathioprine. In patients with AIDS treated with $2^{\prime}, 3^{\prime}$-ddI, the incidence rate varied from $7 \cdot 4 \%$ (seven of 95 patients), ${ }^{14} 15.9 \%$ (seven of 44 patients) ${ }^{15}$ to $23 \cdot 5 \%$ (12 of 51 patients). ${ }^{18}$ It should be noted that in this study drug induced acute pancreatitis was only reported in adults and that in paediatric patients the incidence of asparaginase, corticosteroid, or valporic acid induced acute pancreatitis, or all three, may be more frequent. ${ }^{3-6}$

Severity of drug induced acute pancreatitis was low in our study. This differs from published reports, which show a high incidence of fatal outcome at least from azathioprine, ${ }^{17}$ 19-26 ddI, ${ }^{11-16} 1827$ frusemide, ${ }^{28-34}$ and hydrochlorothiazide. ${ }^{2} 3536$ However, such a high incidence probably does not reflect clinical routine (Table III). Most studies on drug induced acute pancreatitis are case reports that are meant to serve as a warning or signpost for other clinicians. This explains why there are more reports on severe than mild cases.

Furthermore, all fatal cases after an intake of azathioprine occurred after renal transplantation, and all ddI induced cases coincided with AIDS, both underlying diseases being not infrequently associated with acute pancreatitis. Of the three patients with fatal frusemide pancreatitis, one had a myocardial infarction and the other a cardiac problem, in addition, ${ }^{30}$ and the third patient was an alcoholic with pancreatic calcifications, a sign of chronic pancreatitis, who died of renal failure in a diabetic coma. ${ }^{31}$ Three of the five fatal hydrochlorothiazide $^{235}$ cases were treated at a time when modern intensive treatment of acute pancreatitis was unknown.

In accordance with our findings, there are no fatal cases of acute pancreatitis in published reports following mesalazine/sulfasalazine, ${ }^{37-52}$ oestrogens, ${ }^{53} 54$ and rifampicin. ${ }^{55}$

Despite the low incidence and the moderate severity of drug induced acute pancreatitis, all patients with acute pancreatitis of unknown aetiology should be carefully questioned on drugs possibly responsible for the induction of the disease. In positive cases, the drug held responsible should be omitted to reduce the possibility of further episodes of acute pancreatitis.

The authors give their thanks to all contributors to the study and a complete list is available from the authors.

1 Zion MM, Goldberg B, Suzman MM. Corticotrophin and cortisone in the treatment of scleroderma. $Q \mathcal{F ~ M e d ~} 1955$ 24: 215-27.

2 Johnston DH, Cornish AL. Acute pancreatitis in patients receiving chlorothiazide. FAMA 1959; 170: 1054-6.

Mallory A Kern F Jr. Drug-induced pancreatitis: a critical review. Gastroenterology 1980; 78: 813-20.

Dobrilla G, Felder M, Chilovi F. Medikamentös induzierte akute Pankreatitis. Schweiz Med Wochenschr 1985; 115: akute 8 .

5 Dobrilla G, Felder M, Chilovi F. Sichere Zusammenhänge wischen Medikamenten und Pankreatitis. Dtsch Med Zwischen Medikamenten und Pankreatitis. Dtsch Med Wochenschr 1986; 111: 868-70.

6 Mallory A, Kern F. Drug-induced pancreatitis. Baillière Clin Gastroenterol 1988; 2: 293-307.

7 Bale JF Jr, Gray PE, Madsen JA. Monitoring of serum amylase levels during valproic acid therapy. Ann Neurol 1982; 11: 217-8. 
8 Nguyen DL, Wilson DA, Engelman ED, Sexauer CL Nitschke R. Serial sonograms to detect pancreatitis in children receiving L-asparaginase. South Med f 1987; 80 1133-6.

9 Bank L, Wright JP. 6-Mercaptopurine-related pancreatitis in 2 patients with inflammatory bowel disease. Dig Dis Sci 1984; 29: 357-9.

10 Haber CJ, Meltzer SJ, Present DH, Korelitz BI. Nature and course of pancreatitis caused by 6-mercaptopurine in the treatment of inflammatory bowel disease. Gastroenterology 1986; 91: 982-6.

11 Yarchoan R, Pluda JM, Thomas RV, Mitsuya H, Brouwers $\mathrm{P}, \mathrm{Wyvill} \mathrm{KM}$, et al. Long-term toxicity/activity profile of $2^{\prime}, 3^{\prime}$-dideoxyinosine in AIDS or AIDS-related complex. Lancet 1990; 335: 526-9.

12 Lambert JS, Seidlin M, Reichman RC, Plank CS, Laverty M, Morse GD, et al. 2',3'-dideoxyinosine (ddI) in patients with the acquired immunodeficiency syndrome or AIDS-related complex. A phase I trial. $N$ Engl $f$ Med 1990; 322: 1333-40.

13 Cooley TP, Kunches LM, Saunders CA, Ritter JK, Perkins CJ, McLaren C, et al. Once-daily administration of $2^{\prime}, 3^{\prime}$ dideoxyinosine (ddI) in patients with the acquired immunodeficiency syndrome or AIDS-related complex. Results of a phase I trial. $N$ Engl $f$ Med 1990; 322 1340-5.

14 Butler KM, Husson RN, Balis FM, Brouwers P, Eddy J, El-Amin D, et al. Dideoxyinosine in children with symptomatic human immunodeficiency virus infection. N Engl f Med 1991; 324: 137-44

15 Seidlin M, Lambert JS, Dolin R, Valentine FT. Pancreatitis and pancreatic dysfunction in patients taking dideoxyinosine. AIDS 1992; 6: 831-5.

16 Moyle GJ, Nelson MR, Hawkins D, Gazzard BG. The use and toxicity of didanosine (ddI) in HIV antibody-positive individuals intolerant to zidovudine (AZT). $Q 7 \mathrm{Med}$ 1993; 86: 155-63.

17 Sturdevant RAL, Singleton JW, Deren J, Law DH, McCleery JL. Azathioprine-related pancreatitis in patients with Crohn's disease. Gastroenterology 1979; 77: 883-6.

18 Maxson CJ, Greenfield SM, Turner JL. Acute pancreatitis as a common complication of $2^{\prime}, 3^{\prime}$-dideoxyinosine therapy in the acquired immunodeficiency syndrome Am $\mathcal{f}$ Gastroenterol 1992; 87: 708-13.

19 Nogueira JR, Freedman MA. Acute pancreatitis as a complication of imuran therapy in regional enteritis. Gastroenterology 1972; 62: 1040-1.

20 Kawanishi H, Rudolph E, Bull FE. Azathioprine-induced acute pancreatitis. N Engl f Med 1973; 289: 357.

21 Huizenga KA, Shorter RG, Phillips SF. Pancreatitis: a specific complication of azathioprine treatment of Crohn's disease. Gastroenterology 1976; 70: A-37/895.

22 Paloyan D, Levin B, Simonowitz D. Azathioprine-associated acute pancreatitis. Am $\mathcal{F}$ Dig Dis $1977 ; 22$ : 839-40.

23 Taft PM, Jones AC, Collins GM, Halasz NA. Acute pancreatitis following renal allotransplantation. A lethal complication. Am f Dig Dis 1978; 23: 541-4.

24 Isenberg JN. Pancreatitis, amylase clearance, and azathioprine. $\mathcal{F}$ Pediatr 1978; 93: 1043-4.

25 Guillaume P, Grandjean E, Malé P-J. Azathioprine-associated acute pancreatitis in the course of chronic active hepatitis. Dig Dis Sci 1984; 29: 78-80.

26 Roblin X, Becot F, Jacquot JM, Nairf A, Abinader J, Monnet D. Pancréatite aiguë sous azathioprine. Ann Monnet D. Pancréatite aiguë so

27 Bouvet E, Casalino E, Prevost MH, Vachon F. Fatal case of $2^{\prime}, 3^{\prime}$-dideoxyinosine-associated pancreatitis [Letter] Lancet 1990; 336: 1515.

28 Wilson AE, Mehra SK, Gomersall CR, Davies DM. Acute pancreatitis associated with frusemide therapy [Letter] Lancet 1967; i: 105

29 Jones PE, Oelbaum MH. Frusemide-induced pancreatitis. $B M F$ 1975; 1: 133-4.

30 Strunge P. Frusemide-induced pancreatitis? [Letter]. BMf 1975; 2: 434.

31 Buchanan N, Cane RD. Frusemide-induced pancreatitis [Letter]. BMf 1977; 2: 1417.
32 Call T, Malarkey WB, Thomas FB. Acute pancreatiti secondary to furosemide with associated hyperlipidemia. Am f Dig Dis 1977; 22: 835-8.

33 Kristensen BØ, Skov J, Peterslund NA. Frusemide-induced increases in serum isoamylases. $B M F$ 1980; 281: 978 .

34 Stenvinkel P, Alvestrand A. Loop diuretic-induced pancreatitis with rechallenge in a patient with malignant hypertension and renal insufficiency. Acta Med Scand 1988; 224: 89-91.

35 Wenger J, Gross PR. Acute pancreatitis related to hydrochlorothiazide therapy [Abstract]. Gastroenterology 1964; 46: 768.

36 Eckhauser ML, Dokler MA, Imbembo AL. Diuretic-associated pancreatitis: a collective review and illustrative cases. Am f Gastroenterol 1987; 82: 865-70.

37 Block MB, Genant HK, Kirsner JB. Pancreatitis as an adverse reaction to salicylazosulfapyridine. $N$ Engl f Med 1970; 282: 380-2.

38 Suryapranata $\mathrm{H}$, De Vries $\mathrm{H}$, et al. Pancreatitis associated with sulphasalazine. BMF 1986; 292: 732 .

39 Chiba M, Horie Y, Ishida H, Arakawa H, Masamune O. A case of salicylazosulfapyridine (salazopyrin)-induced cute pancreatitis with positive lymphocyte stimulation test (LST). Gastroenterol fpn 1987; 22: 228-33.

40 Poldermans $\mathrm{D}$, van Blankenstein $\mathrm{M}$. Pancreatitis induced by disodium azodisalicylate. Am $\mathcal{F}$ Gastroenterol 1988; 83: 578-80.

41 Aubry P, Alandry G, Lemiere C. Pancréatite aiguë au cours d'un traitement par salazosulfapyridine. Presse Med 1989 18: 80

42 Grimaud JC, Maillot A, Bremondy A, Thervet L, Salducci J. Faut-il toujours accuser la sulfapyridine? A propos d'un cas de pancréatite aiguë induite par la mésalazine. Gastroenterol Clin Biol 1989; 13: 432

43 Deprez P, Descamps C, Fiasse R. Pancreatitis induced by 5 -aminosalicylic acid. Lancet 1989; ii: 445-6.

44 Sachedina B, Saibil F, Cohen LB, Whittey J. Acute pancreatitis due to 5-aminosalicylate. Ann Intern Med 1989, 110: $490-2$

45 Fiorentini MT, Fracchia M, Galatola G, Barlotta A, de la Pierre M. Acute pancreatitis during oral 5-aminosalicylic acid therapy. Dig Dis Sci 1990; 35: 1180-2.

46 Isaacs $\mathrm{KL}$, Murphy D. Pancreatitis after rectal administration of 5-aminosalicylic acid. 7 Clin Gastroenterol 1990; 12 $198-9$.

47 Eckardt VF, Kanzler G, Rieder H, Ewe K. 5Aminosalicylsäure-assoziierte Pankreatitis. Dtsch Med Wochenschr 1991; 116: 540-2.

48 Romero Castro R, Jiménez Sáenz M, Pellicer Bautista FJ, Domínguez Palomo S, Herrerías Gutiérrez JM. Pancreatitis aguda por ácido 5-aminosalicílico. Rev Esp Enf Dig 1991; 79: 219-21.

49 Delgado Fontaneda E, Garcia Campos F, Ruiz Rebollo L Ibarra Peña B, Moretó Canela M. Pancreatitis aguda por salazopirina. Una asociación excepcional. Rev Esp Enf Dig 1991; 79: 439-40.

50 Tran K, Froguel E, Jian R, Lemann M, Modigliani R. Acute pancreatitis induced by mesalazine. 7 Clin Gastroenterol 1991; 13: 715

51 Abdullah AMA, Scott RB, Martin SR. Acute pancreatitis secondary to 5-aminosalicylic acid in a child with ulcerative colitis. I Pediatr Gastroenterol Nutr 1993; 17: 441-4.

52 Garau $P$, Orenstein SR, Neigut DA, Kocoshis SA Pancreatitis associated with olsalazine and sulfasalazine in children with ulcerative colitis. $\mathcal{F}$ Pediatr Gastroenterol Nutr children with ulcerat $18: 481-5$.

53 Glueck CJ, Lang J, Hamer T, Tracy T. Severe hypertriglyceridemia and pancreatitis when estrogen replacement therapy is given to hypertriglyceridemic women. 7 Lab Clin Med 1994; 123: 59-64.

54 Glueck CJ, Scheel D, Fishback J, Steiner P. Estrogeninduced pancreatitis in patients with previously covert familial type V hyperlipoproteinemia. Metabolism 1972; 21: 657-66.

55 Mattson K Side effects of rifampicin. A clinical study (Dissertation). Helsinki, Medical Faculty of the University of Helsinki, 1973: 1-52. 